\title{
PHYTOCHEMICAL AND MEDICINAL STUDY OF LANTANA CAMARA LINN. (VERBENACEAE) - A REVIEW
}

\section{LALITA BATTASE*, DAKSHA ATTARDE}

Department of Pharmacognosy, MGV's Pharmacy College, Nashik-422003, Maharashtra, India. Email: battaselalita@gmail.com

Received: 25 May 2021, Revised and Accepted: 02 August 2021

\section{ABSTRACT}

Lantana camara is a plant from the family - Verbenaceae. It is found in many states of India, mostly in Jammu-Kashmir, Himachal Pradesh, Tamil Nadu, South India, Uttar Pradesh, and several parts of Maharashtra and other countries also. Mainly in disturbed areas, including roadside, railway tracks, and canals. It is an ornamental plant but, in ancient times, it was used traditionally. The plant having various traditional uses. Parts of plant extracts are used traditionally such as the healing of wounds, cuts, skin itches, and eczema. The plant containing many more phytoconstituents such as alkaloids, glycosides, saponins, steroids, terpenoids, carbohydrates, flavonoids, and coumarins. It has various pharmacological activities antioxidant, antimicrobial, antibacterial, antifungal, antiulcerogenic, anthelmintic, anti-hyperglycemic, anti-inflammatory, analgesic, anticancer, antitubercular, etc. It also having mosquito larvicidal activity. This review article was written by the study of many research and review articles from 1956 to March 2021 in which 72 articles were cited. This article reviewed different phytochemicals present in L. camara. The review draws attention to the traditional uses, analytical work, pharmacological activities, and toxicology of this plant and also the potential uses of this plant.

Keywords: Lantana camara, Verbenaceae, Antioxidant, Antibacterial, Anti-inflammatory, etc.

(C) 2021 The Authors. Published by Innovare Academic Sciences Pvt Ltd. This is an open access article under the CC BY license (http://creativecommons.org/ licenses/by/4.0/) DOI: http://dx.doi.org/10.22159/ajpcr.2021v14i9.42444. Journal homepage: https://innovareacademics.in/journals/index.php/ajpcr

\section{INTRODUCTION}

Lantana camara is a flowering ornamental plant. It is used in several traditional medicinal preparations and is well known to cure several diseases. It is a major source of various classes of bioactive natural metabolites. From ancient times, flowers are used as pectoral for children, leaves, and fruits of that plant can be used externally in various skin diseases, cuts, and wounds. Stems and roots are used for gargles and toothaches as a toothbrush. The present article is reviewed that the phytochemical, analytical, pharmacological activities, and toxicology of $L$. camara Linn. [1-3].

\section{Synonyms $[4,5]$}

\begin{tabular}{ll}
\hline Marathi & Ghaneri, Tantani \\
Hindi & Raimuniya \\
English & Spanish flag, Wild sage \\
Tamil & Unnichedi \\
Kannada & Kakke, Natahu \\
Telugu & Pulikampa \\
Manipuri & Samballei, Nongballei \\
German & Wandelroschen \\
Arabic & Multawiat Em Kalthoom, Mina Shajary \\
Brazil & Cambara de espinto \\
Spanish & Cinco negritos \\
French & Lantanier, Verbene \\
Malaysia & Ayam, Big sage, Black sage \\
\hline
\end{tabular}

\section{Biological source}

It is a flowering ornamental plant of L. camara Linn. belonging to the family - Verbenaceae [6].

\section{Taxonomy [7]}

\section{Kingdom}

Subkingdom

Superdivision

Division

Class

Subclass
Plantae

Tracheobionta

Spermotophyta

Magnoliophyta

Magnoliopsida Asteridae

\begin{tabular}{ll} 
Order & Lamiales \\
Family & Verbenaceae \\
Genus & Lantana \\
Species & Lantana camara \\
\hline
\end{tabular}

\section{Geographical distribution}

The Wild sage is found in many states in India such as Jammu-Kashmir, South India, and Tamil Nadu, in different parts of Maharashtra, and also in Himachal Pradesh and Uttar-Pradesh. It is found in the Caribbean and Central and northern South America also now dispersed in about 60 tropical and subtropical countries and also temperature parts of the world. It extends from the innate range of the Greater Antilles, the Bahamas, and Bermuda also on the lesser Antilles, through Trinidad and Aruba. It is usually found in beach areas of the United States from South America to northern Mexico and from Georgia through Texas as well as Peru and Brazil and possibly Northern Argentina and Bolivia. It has adapted to the most suitable habitats in tropical and subtropical Africa, Australia, and Asia. It is also found in many African countries including South Africa, Uganda, Kenya, and Tanzania [8-11].

\section{Plant description [12-14]}

L. camara is a low erect or subscadent vigorous shrub with a tetrangular stem, a strong odor of black currents, and stout recurved pickles. The plant is found up to height 1 to $3 \mathrm{~m}$ and width of $2.5 \mathrm{~m}$. Images of plants, flowers, fruits, front, and dorsal view leaf as shown in Fig. 1.

\section{Leaves}

Leaves are ovate or ovate-oblong, crenate serrate, acute or subacute, rugose above, and scabrid on both sides. The leaves are averagely 3-8 cm long and 3-6 cm wide and have a green color. Leaves and stems are roofed with rough hairs. Leaves are the main source of phosphorous and potassium when used as a green mulch.

\section{Inflorescence}

Pairs in the axils of opposite leaves inflorescences are produced, which are compact, dome-shaped 2-3 cm across, and contain 20-40 sessile flowers. 

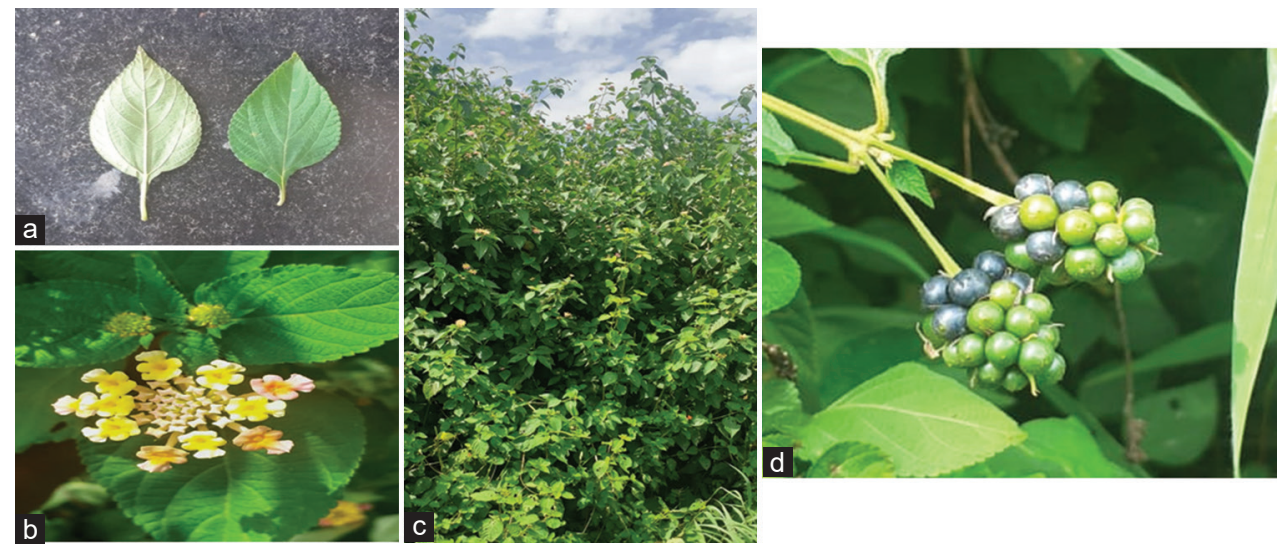

Fig. 1: Images of Lantana camara Linn. (a) Leaf (dorsal and frontal view), (b) Flower, (c) Whole plant, (d) Fruits

\section{Flowers}

Flowers of L. camara are small habitually yellow or orange altering to red or scarlet, in dense axillary heads. The calyx is small, corolla tube slender, the limb spreading 6-7 $\mathrm{mm}$ wide and divided into unequal lobes. Stamen is four in two pairs, which included ovary two ovules, two-celled. Flowering arises between August and March, or all-around year if suitable moisture and light are available and small flowers are held in clusters. Color is usually orange, sometimes varying from white to red in various shades and the flowers usually change colors as they age. In the axillary head, flowers are having a yellow throat almost throughout the year.

\section{Fruits}

The ripe fruits are heavily consumed by birds and frequently eaten by humans in some countries.

\section{Roots}

The root system of this plant is very strong and even after repeated cuttings; it gives out new fresh shoots.

\section{Ecology}

Ghaneri is collected from an area that has about $250 \mathrm{~mm}$ to $2900 \mathrm{~mm}$ of rainfall; it grows on all types of well-drained soil. It tolerates salt spray and keeps out in a dry period very well. Aerial portions of the plant are killed by temperatures of $-2^{\circ} \mathrm{C}$ but quickly grow back. It is colonizing disturbed areas because they are an intolerant pioneer [3]. The species of that plant occur in varied habitats at open unshaded regions which include forests, rainforest edges, wastelands, beach fronts, and spread by activities such as logging or fire. The species also grow well in disturbed areas which include beach areas, roadside, railway tracks, and canals. At early of the second growing (summer) season Lantana can flower. In most places, during the wet, summer months if adequate moisture, light, and temperature are available with flower peaking plants can be a flower. Flowering occurs only in the warmer or wetter months, in drier or cooler regions. Seeds are widely spread, usually by birds but also pets such as cattle, goats, sheep, and also by jackets and foxes [15-18].

\section{Traditional uses}

L. camara is used as a garden decorative plant while in some countries it is implanted as a border to keep out animals. It has many more therapeutic uses, mostly as herbal medicine. On this natural element of plant extract, there has been abundant work conducted in India [19]. Leaves of Lantana show biocidal activity, fungicidal, antimicrobial, nematicidal, and insecticidal. Powder leaves are used for swellings, wounds, cuts, and ulcers and an infusion of the leaves is used for eruptions, eczema, and bilious fever [20]. Lantana oil is used in the treatment of wounds as antiseptic, skin itches, and also reported in the treatment externally for scabies and leprosy [21]. This plant is used as carminative, diaphoretic, tonic, antispasmodic, antiemetic, respiratory disorders (bronchitis, asthma, cold, and cough) and to treat respiratory infections also in the treatment of gastropathy, epilepsy, tetanus, and dysentery. The compound isolated from tantani extract can be reported that is verbascoside, which has been established to pass antitumor activities, immune-suppressive, and anti-microbial. The fruits are used in rheumatism, fistula, tumors, and pustules. The roots are used in rheumatism, malarial, dermatitis, skin rashes, eczema, respiratory tract infections including, tuberculosis and influenza, and mycotic infections [22-24]. An infusion of the entire plant is boiled for tea and the decoction is therapy against cough and it is used as a lotion for wounds and crushed leaves are useful for swellings, cuts, and ulcers [25].

\section{Potential uses}

The sulfate process is on the stems of L. camara carried out to produce printing and writing paper, temporary shelters, and making baskets also used as a fuel for heating and cooking. For many native birds, it may provide vital winter food and shelter. When natural habitat is unavailable a no. of endangered bird species uses its tickets and it is a major liquid source for various species of moths and butterflies. It can be also used for the prevention of erosion and soil compaction. Organic substances of this plant are used for grassland renovation. In Australia, the nursery sector is a brilliant source of income as an ornamental plant. The roots containing substances of the plant are sometimes used in the rubber industry. The plant has been used for biogas production mixed with cow dung and the seeds have additional nutritive value when feeding with wheat straw to sheep. It is used in some household furniture such as chairs and tables are made from the stems, or the small branches are bundled together to make brooms and sometimes used as mulch and firewood [26-28].

\section{Phytochemical constituents}

The literature proposes the plant of L. camara possesses important bioactive compounds, as shown in Fig. 2.

Parts of L. camara such as leaf, stem, and roots contained flavonoids, alkaloids, tannin, protein, catechin, phenol, saponin, steroids, anthraquinone, reducing sugar, and several tri-terpenoids which contain various important phyto molecules such as verbascoside, linaroside, lanatoside, umuhengerin, ursolic acid, carminic acid, caprylic acid, and phytol. These are mostly responsible for using various biological activities [29-32]. The elements of essential oil of Lantana are sabiene, $\beta$-caryophyllene, $\alpha$-humulene, 1,8 - cineole and 8-hydroxy bicycle germacrene, caryophyllene, 1,8-cineol, two rare sesqui-terpenoid humulene epoxide-III, and sabinene [33]. Chemical investigation of the flower and leaves extract to give knowledge of similar lipid and carbohydrate compositions. The flowers carried out carbohydrates more than leaves; although the lipids were more in the leaves extract [34]. Pentacyclic triterpenoids (camangeloyl acid, methyl camaralate, and camaryolic acid), octadecanoic acid, palmitic acid, camaric acid, $\beta$-sitosterol 3-o-beta-D- glycopyranoside, docosanoic acid, lantanolic acid, oleanolic acid, icterogenin, lantadene 
A, lantadene $\mathrm{B}$, and lantadene $\mathrm{C}$ were isolated from the aerial parts of it [35].

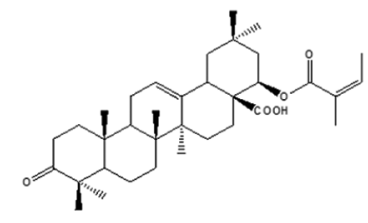

Lantadene A

Lantadene C

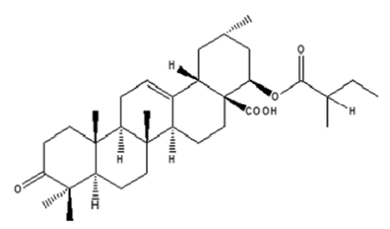

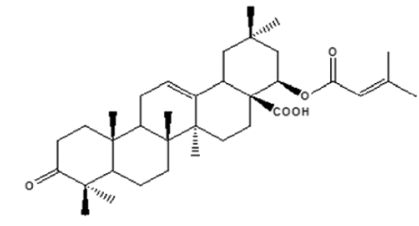

Lantadene B

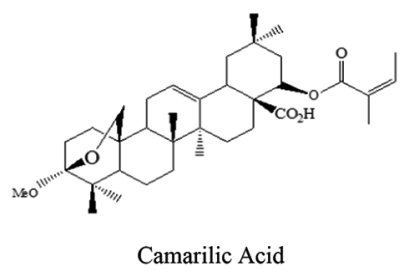

Camarilic Acid<smiles>C[C@H]1CC[C@]2(C(=O)O)CC[C@]3(C)C(=CC[C@@H]4C3CCC3C(C)(C)[C@@H](O)CC[C@]34C)[C@H]2[C@@H]1C</smiles>

Ursolic Acid

Fig. 2: Phytoconstituents of Lantana camara Linn.

Table 1: Essential oils in Lantana camara Linn.

\begin{tabular}{|c|c|c|c|}
\hline $\begin{array}{l}\text { Sr. } \\
\text { No. }\end{array}$ & $\begin{array}{l}\text { Oil } \\
\text { extract }\end{array}$ & Essential oils & References \\
\hline 1 & $\begin{array}{l}\text { Flower } \\
\text { oil }\end{array}$ & $\begin{array}{l}\text { Thymol }(32.3 \%),(\mathrm{E})-\beta \text {-caryophyllene } \\
\text { (13.5\%), } \alpha \text {-humulene }(6.4 \%) \text {, sabinene } \\
(15.6 \%), \beta \text {-phellandrene }(7.1 \%), \\
\text { germacrene D }(6.6 \%)\end{array}$ & $\begin{array}{l}\text { Nea et al. } \\
\text { (2017) }\end{array}$ \\
\hline 2 & $\begin{array}{l}\text { Fruit } \\
\text { oil }\end{array}$ & $\begin{array}{l}\text { (E)- } \beta \text {-caryophyllene }(25.5-32.6 \%) \text {, } \\
\alpha \text {-humulene }(12.4-13.3 \%), \text { limonene } \\
(16.0 \%),(E)-\beta \text {-farnesene }(5.5 \%), \\
\text { bicyclogermacrene }(6.2 \%), \tau \text {-cadinol } \\
(5.0 \%)\end{array}$ & \\
\hline 3 & Leaf oil & $\begin{array}{l}\text { (E)- } \beta \text {-caryophyllene }(40.8 \%) \text {, } \\
\alpha \text {-humulene }(21.2 \%) \text {, sabinene } \\
(9.0 \%) \text {, bicyclogermacrene }(7.9 \%) \text {, } \\
\text { germacrene D }(6.9 \%), \alpha \text {-pinene } \\
(4.4 \%), \beta \text {-elemene }(3.5 \%) \text {, linalool } \\
(0.4-1.9 \%) \text {, sesquithuriferol }(0.3-1.7 \%) \text {, } \\
\text { spathulenol }(0.2-1.5 \%),(E) \text {-nerolidol } \\
\text { and } \tau \text {-cadinol }(0.0-1.0 \%)\end{array}$ & \\
\hline
\end{tabular}

\section{QUALITATIVE ANALYSIS}

\section{Preliminary phytochemical analysis}

Ganatra et al. (2016) studied that preliminary phytochemical analysis of aerial parts of plant extracts of L. camara using various solvents was done qualitative analysis and identification test. In that article for Alkaloids-Hager's test, for Glycosides-Liebermann's test, for Saponins-
Foam test, for Carbohydrates-Molisch's test, for Steroids-Liebermann Burchard test, and for Flavonoids-Lead acetate test was done. As per the researcher's work, the aerial part of plant extract contains various metabolites such as alkaloids, glycosides, saponins, carbohydrates, steroids, terpenoids, flavonoids, coumarins. Phytochemical analysis using n-Hexane extract alkaloids, saponin, steroids, and terpenoids tests are positive. In ethyl acetate extract saponin, steroids, terpenoids, flavonoids, and coumarins tests are positive. In methanol extract glycosides, saponins, terpenoids, carbohydrates, flavonoids, and coumarins tests are positive. In ethanol extract saponin, steroids, terpenoids, carbohydrates, and flavonoids tests are positive [5].

Raj (2017) studied that preliminary phytochemical analysis of leaves and root extract of L. camara using maceration method with solvents separately in acetone, petroleum ether, chloroform, ethyl alcohol, benzene, and water. As per the researcher's phytochemical screening of leaves and roots, solvents extract containing metabolites are, proteins, amino acids, carbohydrates, alkaloids, saponins, phytosterols, phenols, tannins, flavonoids, steroids, and Vitamin C [44].

Kedar et al. (2012) studied the phytochemical screening of successive leaf extract of L. camara with solvents petroleum ether, ethyl acetate, methanol, and water. As per the researcher's work, all solvent extract contains metabolites are saponins, flavonoids, tannins, alkaloids, fats, and oil. In that article Saponins-Foam test, for Flavonoids-Shinoda test, Sulfuric acid test, for Tannins-5\% $\mathrm{FeCl}_{3}$ test, Lead acetate test, Bromine water test, for Alkaloids-Dragendrop's test, Mayer test, for Fats, and oilsolubility test were done. In petroleum ether extract fats and oils test is positive. In ethyl acetate extract tannins and fats and oils test is positive. In methanol extract saponins, flavonoids, tannins, fats, and oil tests are positive. In aqueous extract saponins, flavonoids, tannins, alkaloids, fats, and oil tests are positive [45].

\section{Thin layer chromatography (TLC) analysis}

Ganatra et al. (2016) studied the TLC of aerial parts of $L$. camara with various solvents extracts such as n-Hexane, ethyl acetate, and methanol using different mobile phases for each extract [5] Table 1.

Jain et al. (2011) studied that TLC of ethanolic leaf extract of it can be performed with mobile phase Ethyl Acetate: Methanol (80:20). As per the researcher, the results are shown in Table 2 . For spot visualization, the iodine chamber can be used [46].

Vyas et al. (2014) studied that TLC of oleanolic acid which is isolated from roots of $L$. camara can be performed on a pre-coated plate of Silica G 60 using mobile phase Chloroform: Methanol (95:5) as shown in Table 3. Anisaldehyde-sulfuric acid is used as a spraying reagent [47].

\section{High-performance liquid chromatography (HPLC) analysis}

Vyas et al. (2014) and Liang et al. (2009) studied that HPLC analysis of oleanolic acid which is isolated from roots of L. camara was analyzed by Shimadzu LC 20 ATVP HPLC system. Column- Exsil ODS Column $(250 \mathrm{~cm} \times 4 \mathrm{~mm}$, particle size-5 $\mu)$ in isocratic mode. Mobile phase - acetonitrile: water (85:15 v/v), Column temperature $-30^{\circ} \mathrm{C}$ (const.), the flow rate of mobile phase $-1 \mathrm{ml} / \mathrm{min}$, and Detector - photodiode array detector (Elution was monitored by this detector at $215 \mathrm{~nm}$ ) Table 4. HPLC spectra of standard oleanolic acid showed two peaks at $2.43 \mathrm{~min}$ and $7.01 \mathrm{~min}$ and extracted test sample of oleanolic acid showed at $1.73 \mathrm{~min} ., 2.44 \mathrm{~min}$, and $6.94 \mathrm{~min}$. By observation, the researcher concluded that with some minor impurities

Table 2: TLC analysis of Lantana camara Linn. with their different extracts.

\begin{tabular}{lllll}
\hline Sr. No & Extracts & Mobile phase & Spots \\
\hline 1 & n-Hexane Extract & Ethyl acetate:chloroform $(9: 1)$ & 5 & $0.33,0.42,0.46,0.52,0.56$ \\
2 & Ethyl acetate Extract & n-Hexane:chloroform $(9: 1)$ & 3 \\
3 & Methanol Extract & n-Hexane:chloroform $(9: 1)$ & 4 & $0.45,0.53,0.65$ \\
4 & Ethanol Extract & Ethyl acetate:methanol (8:2) & 3 & $0.48,0.68,0.85,0.91$ \\
\hline
\end{tabular}


Table 3: TLC analysis of Lantana camara Linn. compared with Oleanolic acid standard

\begin{tabular}{lllll}
\hline Sr. No. & Track & Mobile phase & Spots & Rf value \\
\hline 1 & Standard Oleanolic acid & Chloroform: & 1 & 0.51 \\
2 & Extracted test sample & Methanol (95:5) & 1 & 0.50 \\
\hline
\end{tabular}

isolated test sample of oleanolic acid shows resembling HPLC spectra as compared to HPLC spectra of standard oleanolic acid $[47,48]$.

Hitesh et al. (2012) studied that HPLC analysis of pentacyclic triterpenoids isolated from aerial parts of L. camara was analyzed using Column-Phenomenex, C18, $5 \mu \mathrm{m}, 250 \times 4.6 \mathrm{~mm}$, mobile phase-pump A (Acetic acid 0.5\%), and pump B (water: acetonitrile [90:10 v/v]), flow rate $-1 \mathrm{ml} / \mathrm{min}$ with gradient elution. The volume of injection - $20 \mu \mathrm{l}$, detector - SPD-M20A prominence diode array detector at $242 \mathrm{~nm}$. As per research work, two peaks with similar retention times (RT) were observed at $18.496 \mathrm{~min}$ and $18.246 \mathrm{~min}$. From that observation, it is shown that an isolated compound of pentacyclic terpenoids is present in the aerial part of plant extract [49].

High-performance thin-layer chromatography (HPTLC) analysis Jamal et al. (2018) studied the isolation and validation of ursolic acid from leaves of L. camara by HPTLC. Extraction was carried out with different methods maceration, reflux, Soxhlet, and UAE using different solvents ethanol, methanol, acetone, and chloroform. The methanolic extract gives a high \% of yield, on that basis for HPTLC analysis methanolic extract was used. Instrument-Camag Linomat V (Switzerland), Stationary phase-Precoated silica gel aluminum plates 60F $254(20 \times 10 \mathrm{~cm})$, mobile phase-Toluene: acetone:formic acid (7.8: 2.2: 0.15). Scan at $540 \mathrm{~nm}$ and Rf of ursolic acid was observed 0.49 [50].

Jaafar et al. (2018) studied the detection of phenolic acids in leaves extract of L. camara by HPTLC. Extraction was done with method maceration using petroleum ether and ethanol as a solvent followed by acid hydrolysis was done with crude ethanolic extract in reflux, then fractionation was done with solvents petroleum ether, chloroform, ethyl acetate, and n-butanol. The chloroform and ethyl acetate fractions were analyzed by HPTLC compared with standards. For this instrument was used and is CAMAG-Laboratory, Switzerland, plates were used silica gel 60 F $254(20 \times 10 \mathrm{~cm})$, mobile phase - chloroform: ethyl acetate: formic acid (25: 20: 5), at 254 and $366 \mathrm{~nm}$ wavelength and spray - $5 \%$ alcoholic $\mathrm{KOH}$. Phenolic acids detected in chloroform and ethyl acetate fractions are Gallic acid, caffeic acid, and p-coumaric acid. Gallic acid detected only ethyl acetate fractions [51].

Venkatachalam et al. (2010) studied the detection of flavonoids from dried fruits of L. camara by HPTLC compared with Rutin as a standard. The successive extraction method was used with solvents petroleum ether, chloroform, methanol, and water. The methanolic extract was used for detection of flavonoids by HPTLC, Mobile phase used was ethyl acetate: methanol:water (10: 1.65: 1.35). At $366 \mathrm{~nm} 5$ spots of active constituents were confirmed [52].

\section{QUANTITATIVE ANALYSIS}

\section{Total phenolic content (TPC)}

Anwar et al. (2013) studied that the determination of TPC from leaves and flowers of L. camara with different concentrations of ethanol and methanol extracts was done by Folin-Ciocalteu method. The amount of TPC present in leaves and flowers extracts of it was compared with gallic acid standard. The result was analyzed by Gallic Acid Equivalent (GAE) g/100 g of dry weight (DW). About 80\% methanol and 80\% ethanol contained higher TPC as compared to absolute ethanol. About $80 \%$ methanol flowers extract of TPC is higher (21.45 g GAE/100 g DW) than leaves extract (18.37 g GAE/100 g DW) [53].

El-Sayed et al. (2017) studied that TPC of leaves, stem, and flower of L. camara was determined. Leaves, stems, and flowers are extracted separately with $85 \%$ methanol. Methanolic extract further defatted with petroleum ether and fractionated with solvents such as dichloromethane, ethyl acetate, n-butanol, and water. The TP content was determined by the Folin-Ciocalteu method, gallic acid is used as a standard. In that methanolic flowers, the extract contains higher (180.3 $\mathrm{g} \mathrm{GAE} / \mathrm{g}$ of extract) TPC than stems (57.28 g GAE/g of extract), and leaves (148.97 g GAE/g of extract) extract and ethyl acetate fractions also gives higher (301.5 g GAE/g of extract) TPC than other solvent fractions [54].

\section{Total flavonoid content (TFC)}

Anwar et al. (2013) studied that the determination of TFC from leaves and flowers of L. camara with different concentrations of ethanol and methanol extracts was done by $\mathrm{AlCl}_{3}$ method. The amount of TFC present in leaves and flowers extracts of it was compared with the standard. The result was analyzed by catechin equivalent (CE) g/100 g of DW. As per the researcher, $80 \%$ methanol and $80 \%$ ethanol contained higher TFC as compared to absolute ethanol. About $80 \%$ methanol flowers extract of TFC is higher (13.76 g CE/100 g DW) than leaves extract (13.41 g CE/100 g DW) [53].

El-Sayed et al. (2017) studied that the TFC of leaves, stems, and flowers of L. camara was determined. Leaves, stems, and flowers are extracted separately with $85 \%$ methanol. The methanolic extract was further defatted with petroleum ether and fractionated with solvents such as dichloromethane, ethyl acetate, n-butanol, and water. The TF content was determined $\mathrm{AlCl}_{3}$ method; rutin is used as a standard. In that methanolic flowers extract contains higher (99.7 mg RE eq./g of extract) TFC than stems (42.63 mg RE eq./g of extract) and leaves (63.76 mg RE eq./g of extract) extract and ethyl acetate fractions also gives higher (126.17 mg RE eq./g of extract) TFC than other solvents fractions [54].

\section{Gas chromatography mass spectroscopy (GC-MS) analysis}

Mortada et al. (2017) studied that essential oil extracted from leaves and flowers of L. camara by Clevenger-type apparatus were injected to GCMS technique. The identification of the components of each essential oil was done by their molecular formula (MF), RT, molecular weight (MW), mass fragmentation pattern, and concentration (\%). The researcher found 47 essential oil components from leaves and 40 components from flowers. Those compounds are majorly classified as monoterpenes, sesquiterpenes, and fatty acids. The major compound detected in essential oil of leaves extract were 7(11)-selinen-4 $\alpha$-ol (14.5\%), 4a,7methano-4a H-naphth [1,8a-b] oxirene, octahydro-4,4,8,8- tetramethyl $(6.5 \%)$, cedrenol $(6.5 \%), \delta$-cadinene $(5.8 \%)$, linoleic acid $(6.3 \%)$, guaiol $(5 \%)$, and spathulenol (5\%) and the compounds in the essential oil of plant flowers were found farnesyl acetone (7.15\%), cedrenol $(10.71 \%)$, clovane $(5.08 \%)$, germacron $(5.21 \%)$, and methoxyeugenol $(5.06 \%)$. The structure of majorly identified compounds of essential oil of leaves and flowers of it is shown in Fig. 3. [54].

\section{Pharmacological activities}

\section{Antioxidant activity}

Bhakata et al. (2009) studied that in vivo and in vitro methanolic and ethanolic extract of L. camara shows significant antioxidant activity. In that leaves extract exhibited strong antioxidant activity. The methanolic extract from the stem of Wild sage showed weak antioxidant activity. In vitro, antioxidant activity was measured by nitric oxide freeradical scavenging method and DPPH radical scavenging activity. The antioxidant activity of icterogenin, lantadene $\mathrm{A}$, lantadene $\mathrm{B}$, and lantadene $\mathrm{C}$ was examined using DPPH. Lantadene A and B had the highest scavenging activity, while lantadene $C$ and icterogenin showed a lesser antioxidant effect. The extract showed high antioxidant properties in both assays. In vivo studies, ethanolic leaves extract of that plant shows significant antioxidant activity on urolithic rats. On the treatment, ethanolic extract decreased the range of lipid peroxidation in the kidneys of urolithic rats [55]. 
<smiles>CC(C)=C1CC[C@]2(C)CCC[C@](C)(O)C2(C)C1</smiles>

7(11) - Selinen-4 $\alpha$-ol<smiles>C=C1CCC2C([C@H]3[C@@H]1CC[C@H]3O)C2(C)C</smiles>

Spathulenol<smiles></smiles>

Credenol<smiles>C[C@H]1CCC2=C(C[C@](C)(C(C)(C)O)CC2)[C@@H]1C</smiles>

Guaiol<smiles>C=CCc1cc(OC)c(O)c(OC)c1</smiles><smiles>CC1=C[C@]2(C)C(=C(C)CC[C@@H]2C(C)C)CC1</smiles>

$\delta$-Cadinene<smiles>CC1=CCC(=C(C)C)CC(=O)C(C)=CCC1</smiles>

Germacron

\section{Methoxyeugenol}

Fig. 3: The structure of major compound found in the essential oil of leaves and flowers of Lantana camara Linn.

Table 4: Pharmaceutical formulation with their biological role using Lantana camara Linn. [37-43]

\begin{tabular}{|c|c|c|c|c|}
\hline Sr. No. & Extracts & $\begin{array}{l}\text { Pharmaceutical } \\
\text { formulations }\end{array}$ & Biological role & References \\
\hline 1 & Leaves & Herbal gel & Anti-inflammatory activity & Pawar et al. (2013) \\
\hline 2 & Leaves & Herbal Hand wash & Washing and cleaning hands to removing soil, dirt, and microorganism & Bhor et al. (2018) \\
\hline 3 & Leaves & $\begin{array}{l}\text { Silver nanoparticles } \\
\text { with extract }\end{array}$ & Wound healing activity, anti-inflammatory activity, antibacterial activity & Lakshmi et al. (2021) \\
\hline 4 & Leaves & Herbal gel & Topical therapy on acne vulgaris & Dange et al. (2020) \\
\hline 5 & Flower & Natural colorant & Natural colorant with preservatives for food, juices, etc. & $\begin{array}{l}\text { Annegowda et al. } \\
\text { (2020) }\end{array}$ \\
\hline 6 & $\begin{array}{l}\text { Oil extract } \\
\text { from Flower }\end{array}$ & Ointment & $\begin{array}{l}\text { The better alternative of Povidone-iodine, which has some delayed wound } \\
\text { healing action. }\end{array}$ & Satyajit et al. (2017) \\
\hline 7 & Leaves & Herbal Cream & Topical application on skin infection, antibacterial activity & Pandit et al. (2017) \\
\hline
\end{tabular}

\section{Antimicrobial activity}

Kedar et al. (2012) studied that, in vitro antimicrobial activity of dried leaves extract of L. camara on species of Escherichia coli, Bacillus subtilis, and Staphylococcus aureus by the Agar Plate Method. Four types of solvent extracts can be used for maximum zone inhibition. On ethyl acetate extract showed resistant by $S$. aureus and $E$. coli. Aqueous extract showed resistant by B. subtilis. Methanolic extract showed moderate, aqueous extract showed minimum, and ether extract showed the highest antimicrobial activity [45].

\section{Antibacterial activity}

Ganjewala et al. (2009) studied that in vitro antibacterial activity of aqueous and organic extract of L. camara leaves was studied against different clinical pathogens. The ethyl acetate and ethanol extract of leaf effectively inhibited the growth of both Gram-positive and negative bacteria. By researcher work, we say that the disc diffusion method showed significant zones of inhibition against test bacteria.
The ethanolic leaf extracts exhibited greater inhibition in the test bacteria. The zone of inhibition was higher in S. aureus, Klebsiella pneumonia, and Proteus vulgaris, moderate inhibition was associated with Vibrio cholerae, Salmonella typhi, E. coli, Enterobacter aerogenes, and very poor inhibition was observed against Staphylococcus epidermidis. The essential oil of $L$. camara exhibited prominent antibacterial activity against all the bacterial strains tested [56].

\section{Antifungal activity}

Mudasir et al. (2017) studied that, in vitro antifungal activity of $L$. camara leaf extract with successive extraction using different solvents, acetone, chloroform, ethanol, and methanol. For this antifungal activity research used the poisoned food technique. In that mycelial growth zone of fungus in Petri plates and percentage inhibition of fungal growth was measured. Antifungal activity of leaf extract was tested on Aspergillus flavus and Aspergillus niger fungal strains. Methanol and Chloroform extract shows maximum zone inhibition [57]. 


\section{Antiulcerogenic activity}

Thamotharan et al. (2010) studied that, in vivo antiulcerogenic activity, pre-treatment with methanol extract of L. camara leaves produced a significant antiulcer effect which can be compared with an aspirin-induced ulcer on rats. The methanolic extract of leaves was administered orally in pyloric ligated rats, ethanol-induced gastric ulcer, and cysteamine-induced duodenal ulcer. The plant extract shows healing of gastric ulcers and also prevents the development of duodenal ulcers in rats. The extract shows dose-dependent antiulcerogenic activity in all models [58].

\section{Mosquito larvicidal activity}

Kumar et al. (2008) studied that, in vitro mosquito larvicidal activity of the methanol and ethanol leaves and flower extract of L. camara was found to have a higher rate of Larvicidal rate against Aedes aegypti. Whereas, in the Culex quinquefasciatus variety, the conc. of extracts has to be increased for a better larvicidal effect. An essential oil obtained from the leaves shows larvicidal activity against important vectors of dengue, malaria, yellow fever, hemorrhagic fever, and Chikungunya [59].

\section{Anthelmintic activity}

Girme et al. (2006) studied that in vitro helminth infection is among the most common infection in men. On selected worms, successive leaf extracts of $L$. camara show significant anthelmintic activity. Anthelmintic activity by methanol extract from the stems, leaves, and roots of the plant was investigated against Pheritima posthuma. The methanolic extract of the stem was found to be more effective. The anthelmintic activity on ethanolic extract was also found to be more active [60].

\section{Anti-hyperglycemic activity}

Ganesh et al. (2010) studied that, in vivo anti-hyperglycemic activity. Oral administration of a methanol extract of L. camara leaves in alloxaninduced diabetic rats showed significant dose-dependent reduction of blood glucose concentration and also promising anti-hyperglycemic activity against alloxan-induced diabetic rats. Aqueous extract of the leaves of it was evaluated using both alloxan-induced hyperglycemic rats and normoglycemic rats also show anti-hyperglycemic activity [61].

\section{Wound-healing activity}

Abdulla et al. (2009) studied that in vivo wound healing activity of ethanolic leaf extract on adult male Wistar rats. Topical application of ethanolic leaf extract on wounds showed increasing wound healing activity. Using excision wound model aqueous extract of leaf showed significant wound healing activity in rats. Topical application of the extract on the wound significantly increased the rate of wound contraction, synthesis of collagen, and decreased wound healing time [62].

\section{Anti-inflammatory and analgesic effect}

Millycent et al. (2017) studied that in vivo anti-inflammatory and analgesic activities of aqueous extract of $L$. camara were studied using animal models. As per the researcher's work, the anti-inflammatory activity was studied using carrageenan-induced lung edema and pleurisy mice, while, the analgesic effect was studied using a formalin pain test in rats. The administered doses exhibited significant $(p<0.05)$ minimal toxic effects, anti-inflammatory and analgesic activity and. Methanolic extracts of the leaves and bark were screened for analgesic activity by carrageenan and histamine-induced paw edema models. Concerning the antipyretic activity, the plant of ethyl acetate and ethanolic extract start dropping the body temperature from $1.5^{\text {th }} \mathrm{h}$ [63].

\section{Anti-cancer activity}

Badakhsan et al. (2011) studied that, in vitro anti-cancer activity. Different solvent extracts such as petroleum ether, chloroform, ethanol, and aqueous extract for L. camara are screened for anticancer activity, in that ethanolic extract shows a better effect. By MTT assay, root and leaf extracts were investigated against Jurkat leukemia cells. The root and leaves extract of it might be studied for further identification and fractionation of new anticancer agents [64].

\section{Antitubercular activity}

Misra et al. (2006) studied that, in vitro antitubercular activity L. camara showed on multiple-drug-resistant. Mycobacterium activity was investigated on HIV-infected persons. The well-in-agar-diffusion method used to estimate minimal inhibitory concentration and potency of extracts was compared with standard drug [65].

\section{Antimutagenic activity}

Barre et al. (1997) studied that, in vivo L. camara showed antimutagenic activity with the compounds $22 \beta$-acetoxylantic acid and $22 \beta$-dimethylacrylacryloxy lantanolic acid. On Swiss mice, the antimutagenicity test was done by micronucleus test. $22 \beta$-acetoxylantic acid and $22 \beta$-dimethylacrylacryloxy lantanolic acid both compounds showed high antimutagenic activity in Mytomycin $\mathrm{C}$ induced Mutagenesis in mice [66].

\section{Hemolytic activity}

Kalita et al. (2011) studied that, in vitro hemolytic activity. Aqueous extract and its solvent fractions were performed hemolytic activity using the modified spectroscopic method at different concentrations $(125,250,500$, and $1000 \mu \mathrm{g} / \mathrm{ml})$ and it exhibited very low hemolytic activity on human erythrocytes. Other solvent extracts and their fractions showed hemolytic activity in the following order: chloroform >hexane and ethyl acetate (50:50) > water > ethanol $>$ methanol [67].

\section{Hepatoprotective activity}

Asija et al. (2015) studied that, in vivo hepatoprotective activity. Dried rind extract of L. camara has studied carbon tetrachloride $\left(\mathrm{CCl}_{4}\right)$ - induced liver damage of male Wistar rats. On the treatment of 28 days, that plant extracts reduced the toxicity of $\mathrm{CCl}_{4}$ on serum markers of liver damage, alkaline phosphatase, alanine aminotransferase, and aspartate aminotransferase. The plant extract also increases the levels of superoxide dismutase and catalase enzymes in rats [8].

\section{TOXICOLOGY}

Due to the high consumption toxicity of L. camara occurs only on animals such as sheep, goats, cattle, pigs, and horses. In humans, poisoning was not shown. In some countries, the ripe fruit of the plant is eaten by humans. Sometimes due to unripe fruit acute toxicity in humans may occur.

A high amount of consumption of L. camara showed toxicity on animals like sheep, cattle, goats, horses, and rats. Active constituents present in this plant, Lantadene A, B, D, and icterogenic acid showed toxicity. Signs of poisoning are photosensitization, jaundice, loss of appetite and sometimes death, liver enlargement, swollen kidney, etc.

The case study, poisoning of L. camara in a kid of Sirohi goat showed consumption of plants causes phototoxicity and some side effects like anorexia, depression, swelling of eyelids, sloughing of the superficial layer of skin, itching of skin. Treatment was given on that toxicity is purgative and liver tonic electrolyte and parental administration of Vitamin B complex and antihistaminic with extract, oral administration of activated charcoal were given $[68,69]$.

\section{CONCLUSION}

The present review article covered several phytoconstituents present in L. camara are alkaloids, glycosides, saponins, steroids, terpenoids, flavonoids, carbohydrates, and coumarins. Some essential oils are also present in this plant. The plant has many traditional as well as potential uses. The plant has many 
pharmacological activities majorly antioxidant, antibacterial, anti-inflammatory, analgesic, anticancer, etc., and also has some medicinal properties to cure various diseases. This review article highlights the potential of that plant can be working in new therapeutic drugs and will offer the base for future research like herbal medicines. It is a very cost-effective and easily available plant, using this plant extract we can formulate many formulations and medicines such as anti-inflammatory or antibacterial cream, analgesic tablet, and anticancer medicine.

\section{AUTHOR FUNDING}

Nil.

\section{AUTHOR CONTRIBUTION}

Both authors are contributed equally.

\section{ACKNOWLEDGEMENT}

The authors are grateful to the Department of Pharmacognosy, MGV's Pharmacy College, Nashik, Maharashtra, India for the support, motivation, and encouragement of this review article.

\section{CONFLICT OF INTERESTS}

The authors declare that there are no conflicts of interest associated with this article.

\section{REFERENCES}

1. Ross IA. Medicinal plants of the world. In: Chemical Constituents. Traditional and Modern Medical Uses. New Jersey: Human Press; 1999.

2. Alice K, Asha S. Medicinal Plants Horticulture Sciences. India: New India Publication Agency; 2007. p. 2.

3. The Wealth of India. The Council of Scientific and Industrial Research, Raw Material. Vol. 6.New Delhi: The Wealth of India; 2005. p. 31-5.

4. Floridata LC: Lantana camara. Florida: Floridata LC; 2007. Available from: https://citeseerx.ist.psu.edu [Last accessed on 2007 Sep 19].

5. Ganatra SH, Gurubaxani SB. Preliminary phytochemical and TLC profiling of Lantana camara leaf extracts. J Chem Pharm Res 2016;8:614-7.

6. Ghisalberti EI. Review Lantana camara L. (Verbenaceae). Fitoterapia 2000;71:467-86

7. Mishra A. Allelopathic properties of Lantana camara, a review. Int Res J Basic Clin Stud 2014;2:32-52.

8. Asija R, Kumar V, Sharma AK. Hepatoprotective activity of Lantana camera against carbon tetrachloride-induced hepatotoxicity in Wister rat. Int J Pharm Erud 2015;4:1-7.

9. Khare CP. Indian Medicinal Plants-an Illustrated Dictionary. Berlin: Springer; 2007.

10. Sanders RW. Taxonomy of Lantana sect. Lantana (Verbenaceae). I. Correct application of Lantana camara and associated names. Sida 2006;22:381-421.

11. Chopra RN, Nayar SI, Chopra IC. Glossary of Indian Medicinal Plants. India: CSIR New Delhi; 1956.

12. Dogra KS, Kohli RK, Sood SK. An assessment and impact of three invasive species in the Shivalik hills of Himachal Pradesh, India. Int J Biodiv Conserv 2009; 1:4-10.

13. Kirtikar KR, Basu BD. Indian Medicinal Plants. Vol. 3. New Delhi: Periodical Expert Book Agency; 1993. p. 1912-5.

14. Arvind NA, Rao D, Ganeshaiah KN, Uma Shankar R, Poulsens JG. Impact of the invasive plant, Lantana camara, on bird assemblages at Male Mahadeshwara reserve forest, South India. Trop Ecol 2010;51:325-38

15. Sharma GP, Raghubanshi AS, Singh JS. Lantana invasion: An overview. Weed Biol Manage 2005;5:157-67.

16. Graaff JL. Lantana camara: The plant and some methods for its control. South Afr Forest J 1986;136:26-30.

17. Duggin JA, Gentle CB. Experimental evidence on the importance of disturbance intensity for invasion of Lantana camara L. In dry rainforest-open forest ecotones in north-eastern NSW, Australia. Forest Ecol Manage 1998;109:279-92.

18. Parsons WT, Cuthbertson EG. Common Lantana. In: Noxious Weeds of Australia, Melbourne. Australia: CSIRO Publishing; 2001. p. 627-32.
19. Ghisalberti EL. Lantana camara L. (Verbenaceae). Fitoterapia 2000;71:467-86.

20. Sharma S, Singh A, Sharma OP. An improved procedure for isolation and purification of lantadene A, the bioactive pentacyclic triterpenoid from Lantana camara leaves. J Med Aromat Plant Sci 1999;21:686-8.

21. Sharma OP, Sharma PD. Natural products of the lantana plant-the present and prospects. J Sci Ind Res 1989;48:471-8.

22. Verma SC, Jain CL, Nigam S, Padhi MM. Rapid extraction, isolation, and quantification of oleanolic acid from Lantana camara roots using microwave and HPLC-PDA techniques. Acta Chromatogram 2013;25:181-99.

23. Dharmagada VS, Tandonb M, Vasudevan P. Biocidal activity of the essential oils of Lantana camara, Ocimum sanctum and, Tagetes patula. J Sci Ind Res 2005;64:53-6.

24. Barreto F, Sousa E, Campos A, Costa J, Rodrigues F. Antibacterial activity of Lantana camara Linn and Lantana montevidensis brig extracts from cariri-ceará, Brazil. J Young Pharm 2010;2:42-4.

25. Verma RK, Verma SK. Phytochemical and termiticidal studies of Lantana camara var aculeata leaves. Fitoterapia 2006;77:466-8.

26. Khanna LS, Prakash R. Theory and Practice of Silvicultural Systems. India: International Book Distributions; 1983. p. 400.

27. Gujral GS, Vasudevan P. Lantana camara L., a problem weed. J Sci Ind Res 1983;42:281-6.

28. Sharma OP, Makkar HP, Dawra RK. A review of the noxious plant Lantana camara. Toxicon 1988;26:975-87.

29. Satish R, Vyawahare B, Natarajan K. Antiulcerogenic activity of Lantana camara leaves on gastric and duodenal ulcers in experimental rats. J Ethnopharmacol 2011;134:195-7.

30. Begum S, Ayub A, Zehra SQ, Siddiqui BS, Chaudhary MI. Leishmanicidal triterpenes from Lantana camara. Chem Biodivers 2014:11:709-18.

31. Sharma OP, Sharma S, Pattabhi V, Mahato SB, Sharma PD. A review of the hepatotoxic plant Lantana camara. Crit Rev Toxicol 2007;37:313-52.

32. Sousa EO, Almeida TS, Menezes IR, Rodrigues FF, Campus AR, Lima SG, et al. Chemical composition of essential oils of Lantana camara L. (Verbenaceae) and synergistic effect of the aminoglycosides gentamicin and amikacin. Rec Nat Prod 2012;6:144-50.

33. Begum S, Wahab A, Siddiqui B, Qamar F. Nematicidal constituents of the aerial parts of Lantana camara. J Nat Prod 2000;63:765-7.

34. Zandi-Sohani N, Hojjati M, Carbonell-Barrachina AA. Bioactivity of Lantana camara L. Essential oil against Callosobruchus maculatus (Fabricius). Chil J Agric Res 2012;72:502-6.

35. Shamsee ZR, Al-Saffar AZ, Al-Shanon AF, Al-Obaidi JR. Cytotoxic and cell cycle arrest induction of pentacyclic triterpenoids separated from Lantana camara leaves against MCF-7 cell line in vitro. Mol Biol Rep 2019;46:381-90.

36. Nea F, Tanoh EA, Yapi TA, Garcia G, Tomi F, Tonzibo ZF. Chemical investigation on leaf. Flower and fruit oils of Lantana camara from Cote d'Ivoire. Natl Prod Commun 2017;12:607-10.

37. Pawar DP, Shamkumar PB. Formulation and evaluation of herbal gel containing Lantana camara leaves extract. Asian J Pharm Clin Res 2013;6:122-4.

38. Bhor RJ, Bhadange SD, Gaikwad RJ, Bhangale CJ. Formulation and evaluation by phytochemical analysis of herbal handwash. Asian J Pharm Res 2018;7:111-21.

39. Muniraja LK, Kiran M, Sai Prasanna K, Rao A. Formulation and characterization of silver nanoparticles loaded with aqueous extract of Lantana camara Linn leaves. Future J Pharm Health Sci 2021;1:21-8.

40. Dange VN, Dinde SR, Doiphode AR, Dhavane SM, Dudhal BA, Shid SJ, et al. Formulation and evaluation of herbal gel containing Lantana camara for management of acne vulgaris. J Univ Sci Technol 2020;22:799-809.

41. Annegowda HV, Tripathy A, Majumdar SP, Harish M. Application of Lantana camara flower extract as a natural coloring agent with preservative action. Asian J Biol Sci 2020;13:361-9

42. Satyajit S, Rath B, Pradhan S, Pattnaik S. Wound healing activity of topical formulation of Lantana camara Linn. Flower water distillate in Wistar rats. Indian J Pharm Pharmacol 2017;4:29-33.

43. Pandit D, Singh RK. Formulation and characterization of an antibacterial cream from Lantana camara leaf extract. Pharm Chem J 2017;4:137-42.

44. Sushama Raj RV. Preliminary phytochemical screening of Lantana camara L., a major invasive species of Kerala, using different solvents. Ann Plant Sci 2017;6:1794-8.

45. Kedar KA, Pawar KT, Chaudhari PD, Chaudhari SR. Pharmacognostic, phytochemical evaluation and comparative antimicrobial activity of Lantana camara (L) var. Aculeate (L) mold. (Verbenaceae). J Pharm Res 2012;5:4125-6. 
46. Jain S, Itoria P, Joshi A, Dubey BK. Pharmacognostic and phytochemical evaluation and Antipyretic activity of leaves of Lantana camara Linn. Int J Biomed Adv Res 2011;2:270-80.

47. Vyas N, Argal A. Isolation and characterization of oleanolic acid from roots of Lantana camara. Asian J Pharm Clin Res 2014;7:189-91.

48. Liang Z, Jiang Z, Fong DW, Zhao Z. Determination of oleanolic acid and ursolic acid in Oldenlandia diffusa and its substitute using highperformance liquid chromatography. J Food Drug Anal 2009;17:69-77.

49. Hitesh HS, Mayukh B, Mahesh AR. Isolation and characterization of chemical constituents of aerial parts of Lantana camara. Int J Pharm Res Biosci 2012;1:198-207.

50. Mahvish J, Mohd A, Ali Z, Mohd M. A comparative study of the extraction methods and solvent selection for isolation, quantitative estimation, and validation of ursolic acid in the leaves of Lantana camara by HPTLC method. Future J Pharm Sci 2018;4:229-33.

51. Jaafar NS, Hamad MN, Alshammaa DA, Abd MR. Preliminary phytochemical screening and high-performance thin-layer chromatography detection of phenolic acids in Lantana camara leaves cultivated in Iraq. Int Res J Pharm 2018;9:59-64.

52. Venkatachalam T, Kumar V, Selvi P, Maske AO, Kumar N. Physicochemical and preliminary phytochemical studies on the Lantana camara L. fruits. Int J Pharm Pharm Sci 2011;3:52-4.

53. Farooq A, Manzoor M, Sultana B, Mushtaq M. Variation in Antioxidant Activity and phenolic and flavonoid contents in the flowers and leaves of Ghaneri (Lantana camara L.) as affected by different extraction solvents. Int J Pharmacol 2013;9:442-53.

54. Mortada ME, Maher MH, Afaf AA, Heba A, Ezzat EA, Eman AM. Total phenolic and flavonoid contents and antioxidant activity of Lantana camara and Cucurbita Pepo (squash) extracts as well as GCMS analysis of Lantana camara essential oils. World J Pharm Res 2017;6:137-53.

55. Bhakata D, Ganjewala D. Effect of leaf positions on total phenolics, flavonoids, and proantho-cuanidins content, and antioxidant activity in Lantana camara L. J Sci Res 2009;1:363-9.

56. Ganjewala D, Sam S, Khan HK. Biochemical compositions and antibacterial activities of Lantana camara plants with yellow. Int J Pharm Ind Res 2009;3:69-77.

57. Mudasir F, Musadiq HB, Mufida F, Kumar A, Jain AK. Antifungal activity of Lantana camara L. leaf extracts in different solvents against some pathogenic fungal strains. Pharmacologia 2017;8:105-12

58. Thamotharan G, Sekar G, Ganesh T, Sen S, Chakraborty R, Kumar NS. Antiulcerogenic effects of Lantana camara Linn. Leaves on in vivo test models in rats. Asian J Pharm Clin Res 2010;3:57-60.

59. Sathish Kumar M, Maneemegalai S. Evaluation of larvicidal effect of Lantana camara Linn against mosquito species Aedes aegypti and Culex quinquefasciatus. Ad Bio Res 2008;2:39-43.

60. Girme AS, Bhalke RD, Ghogare PB, Tambe VD, Jadhav RS, Nirmal SA. Comparative in vitro anthelmintic activity and metha piperita and lantana camara from western India: Dhaka Univ J Pharm Sci 2006;5:5-7.

61. Ganesh T, Sen S, Thilagam E. Pharmacognostic and anti-hyperglycemic evaluation of Lantana camara var. aculeate leaves in alloxan-induced hyperglycemic rats. Int J Res Pharm Sci 2010;1:247-52.

62. Abdulla MA, Hassandarvish P, Ali HM, Noor SM, Mahmoud FH, Bashah NS, et al. Acceleration of wound healing potential by Lantana camara leaf extract in experimental rats. Res J Med Sci 2009;3:75-9.

63. Millycent SA, John MK, Kelvin JK, Piero NM, Mwaniki NE. Evaluation of analgesic, anti-inflammatory, and toxic effects of Lantana camara L. Int J Phytopharmacol 2017;8:89-97.

64. Badakhsan MP, Lachimanan YL, Sreenivasan S. Cytotoxicity and oral acute toxicity studies of Lantana camara leaf extract. Molecules 2011;16:3663-74

65. Misra N, Sharma M, Raja K, Dangi A, Srivastava S, Bhattacharya SM. Chemical constituents and antifilarial activity of Lantana camara against human lymphatic filariid Brugia malayi and rodent filariid Acanthocheilone movitae maintained in rodent hosts. Parasitol Res 2006;100:439-48.

66. Barre JT, Bowden BF, Coll JC, DeJesus J, De La Fuente VE, Janairo GC, et al. A bioactive triterpene from Lantana camara. Phytochemistry 1997;45:321-4.

67. Kalita S, Kumar G, Karthik L, Rao KV. Phytochemical composition and in vitro hemolytic activity of Lantana camara L. (Verbenaceae) leaves. Pharmacologyonline 2011;1:59-67.

68. Sharma OP, Makkar HP, Dawra RK, Negi SS. A review of the toxicity of Lantana camara (Linn.) in animals. Clin Toxicol 1981;18:1077-94.

69. Singh V, Agrawal M, Nagda RK, Sharma MC, Mordia A. A case study of Lantana camara poisoning in Sirohi goat. Int J Rec Sci Res 2018;9:27953-5. 